\title{
ON COMING HOME: ENSURING THE VALIDITY OF THE TRAVELER'S DISCOURSE ON BRAZIL
}

\section{Myriam Ávila}

Universidade Federal de Minas Gerais

Travelers in Brazil in the $19^{\text {th }}$ century, whatever their primary motivations for the journey, envisaged as ultimate goal the diffusion of their experiences and findings in printed version. Confident in the existence and continued growth of a readers' audience and aware of the need to establish their names as explorers, their journals, notes, and drawings were carefully adapted to that audience's repertoire and expectations. The uncertainty of their reception crosses many of these writings, whenever their authors were still unknown in their own countries, which was generally the case - Richard Burton being the outstanding exception. ${ }^{1}$

I will here consider from this viewpoint three travelers ${ }^{2}$ I had the opportunity to translate ${ }^{3}$ W. L. Baron of Eschwege, J.J. von Tschudi, and James W. Wells. Having little in common as to birth, motivation and skills, all three travelled extensively in the interior of the state of Minas Gerais in different periods of the $19^{\text {th }}$ century. Although Eschwege became fairly well known in that part of Brazil (there's a small museum dedicated to him in Diamantina and a locality named after him near Belo Horizonte), it can be safely stated that none of them ever achieved

\begin{tabular}{|l|l|l|l|l|}
\hline Ilha do Desterro & Florianópolis & no 57 & p. 079-095 & jul./dez. 2009 \\
\hline
\end{tabular}


the eminence of Humboldt, Burton, and John Mawe in Europe. ${ }^{4}$ As to their Brazilian reception, the fact that Wells's and Tschudi's works and two of Eschwege's books remained untranslated until the last decade of the $20^{\text {th }}$ century speaks for itself.

Tschudi's case bears some resemblance to Burton's in that he had an official commission in his country of origin, Switzerland, having been assigned an Embassy in Vienna in his fifties. His travels in Brazil covered a large portion of its territory. He was especially interested in the newly founded German colonies and dedicated a great part of his time to the one on the valley of the Mucuri River, in Minas Gerais. On the occasion, he gathered very comprehensive information about the various aspects, physical and political, of the state, with the help of two German engineers ${ }^{5}$ settled in Brazil. Based on this, he wrote a long report divided into twenty topics, which he published as a special feature of the Petermanns Geographischen Mittheilungen in 1862. The vehicle was a relevant one, but the obscurity of his object kept the study from getting as much attention as other writings of his had deserved. Also, the general curiosity that prevailed in the first half of the $19^{\text {th }}$ century concerning Brazil had in part subsided. Brazil was no longer such a mysterious and adventurous site, and its famous gold and diamond reserves in Minas Gerais were mostly spent. So, Tschudi wrote for specialists [not so large in number] and probably little interested in a province that did not stand out for its geographical, zoological or botanic features.

Eschwege, on the opposite, arrived soon after the Portuguese royal family had fled to Brazil and its harbors were opened to foreign ships. He came as a mineralogist in the service of the Portuguese Crown in 1809 and stayed until 1821, leaving two months before the Proclamation of Independence. Eschwege wrote a series of articles and books on Brazil, most of them published in Germany between 1817 and 1833. The last and best known is Pluto Brasiliensis, of which there is a mention in Karl Marx's Das Kapital, though in indirect quotation. Friedrich Renger informs us $^{6}$ that the first book the mineralogist wrote on coming 
back to Germany, Brazil, the New World, had three editions in 1824, 1827 and 1830, which in fact, according to the commentator, would establish the book as a publishing success (11). However, this can give the contemporary reader a false impression of its acceptability and large audience that the author's perigraphy will not corroborate. Letter exchanges between him and his publishers display the need to convince them of the importance of printing his books (Eschwege had a plan to issue one every two years), that is, that he felt the need to assert the scientific accuracy of the information gathered. In the preface to Brazil, the New World, he complains of the poor lay out of a previous publication, which hindered it from being translated into English, since the publishers in that country did not believe it was an original work. And adds: "Mr. Vieweg from Braunschweig promised me, for this reason, to provide the present work with improved graphic aspect. I hope he will be true to his word and facilitate its ample dissemination" (Eschewege, 1: 54)

The need to publish in order to get known overpowers the concerns with the structure of the text. In a time when the totality and "roundedness" of a narrative were cherished features (discontinuous picaresque stories were going out of fashion), Eschwege's and other travel books were assembled from a hodge-podge of texts, lists, glossaries, transcriptions and commentaries which imagined the reader as a small shop customer who could pick what he pleased from a varied display. At the same time, the fragmentariness of the contents was seen as a flaw: Eschwege offers excuses for it, assuring that there is "a unifying principle" presiding over the work, "despite its fragmentary form" (1:53). It could not be otherwise, he reasons, since his object is "a little known and explored land," from which no "harmonious, in all parts finished" portrait can be drawn. His Brazil, a New World comprises translations from laws and regulations concerning the extraction and controlling of diamonds, price tables and geographical distribution of stones, a report on rocks to be found in the country, information about various indigenous tribes, and so on, along with his travel journal. The 
subsequent volumes he intends to print will be equally disconnected. Publishing was his main concern, and his anxiety to seize the opportunity of issuing a new book made him sacrifice parts that still needed development, in order to avoid delay: "That map should have been annexed to my Geognostischen Gemälde von Brasilien (Weimar, 1822), but the alloted time did not allow it" (1:194).

Accuracy and originality were the features that best recommended a book of this sort. So Eschwege: "In what concerns the statistical part of my work, I must explain that the informed data are correct, authentic, gathered as they were from the purest sources, thanks to my condition as a public servant" (1: 53). Considering, however, that the greatest part of his books consisted of travel narrative, the latter might be seen as a kind of extra that had to be smuggled into the volume. On the other hand, the narrative portions of the text functioned as a guarantee of veracity whose legitimating power came almost entirely from literary tradition, where the first person point of view can be seen as a development from oral narration. What may appear to us now as very frail evidence would most certainly be accepted at the time as a bona fide report. In still another approach to the subject, the two parts - the informational and the narrative - can be seen as supporting one another: the data was validated by on-the-spot knowledge while having been on the spot was proved by the collected data. The fictional source of the convincing procedure, well known since Robinson Crusoe (1719) widely read in all of Europe - far from impairing the effect, almost supported it. ${ }^{7}$ A further supporting frame for truthfulness in travel books included extensive knowledge of previous reports. The Viscount of Courcy puts himself "under the guardian aegis of the masters who preceded me, with no other pretension than that of having been true in every part of what is here narrated" (129).

A supplementary token of veracity was the occasional insertion of Portuguese phrases and words in the German text. This also served the need for exoticism. Eschwege includes in the first part of Brazil, a New World a "dictionary of the coroado language" with hundreds of words. 
Wells writes a note for every exotic term, with its phonetic transcription. A further "requirement" that had born itself into the scientific/travel book genre early in its development was the encounter with dangerous beasts and native Indians. Travels in Brazil did not often furnish this kind of danger in the $19^{\text {th }}$ century, and the travelers had to make do with some normal size snakes, not all of them poisonous. This comes as a drawback especially for Wells who, as a young unknown traveler, had hoped for some adventurous encounters to make his narrative more appealing:

Certainly, if a very small fraction of the expected dangers had been met with, my exploration would probably have ended in disaster, but as I met with no marauding Indians or quilombeiros, nor prowling onças, nor pathless forests, nor malignant fevers, and only a skirmish with the peccaries, it was really not worth mentioning. (2: 161)

As the century advances, however, there can be observed a growing distinction between scientific and travel reports. Tschudi clearly opts for the first kind, which does not hinder him from offering his personal comments on a diplomatic issue concerning the German colony of Mucuri: "the abovementioned brochure is the expression of odious partiality, which soils an honorable man in a most repulsing way" (Tschudi \& Halfeld 130-31). James Wells, on the other hand, leans to the literary appeal of the travel narrative. But, again, he cannot dispense with accurate data related to British economic interests in Brazil. His first chapter displays the most distinctive signs of literary polishment, both in the sense that the writing is more carefully worked and in the recourse to conventional tokens of literariness: "Let us imagine ourselves aboard one of the steamships..." or "A sea voyage has been so often described that it need not be here enlarged upon" (Wells, Exploring 54). Consistently, he refers to the book in the preface as his "first literary effort." 
The fact remains that a published book, or books, transforms an anonymous traveler into an author. If none of the mentioned authors had as primary intention, on setting out for Brazil, to become a writer, all of them were eager to publish their reports when they came back home. More than that, the idea of putting their experiences in print struck them early enough on their journey. They were well aware of the opportunity that being in a distant exotic country (over which their different homelands had no jurisdiction) represented and knew that first-hand information would be valued by their country people. So, they kept diaries and gathered objects of various kinds, drew from nature, when they had the talent, or associated with a cartographer, as Tschudi did. On coming home, they had enough material for composing their books.

Although, as Robert Darnton points out, it is impossible to reconstruct exactly the presuppositions of readers in past centuries 8 , the way the travelers organized the collected material to compose a book can indicate what they thought would meet their readers' expectation. Richard Burton's elaborations on the genre show his preoccupation with the appraisal of future readers:

Books of travel, it may be remarked, depend for permanent character upon the opinion of "experts" - that is to say, of those who live, or who have lived, amongst the scenes depicted. There is a well-known work, much read in England, but called in Egypt the "Romance of the Nile"; despite many editions, it is dying the death. (30)

and his awareness of the bearing of form in the conveyance of information:

It was judged better to place before the reader certain portions in diary form, not to spare myself the toil of trouble of "digesting" but to present the simplest and most natural picture of travel. (11) 
In the almost forty years that separate the publishing of Eschwege's and Tschudi's books we can observe the increased consistency in writing, including both continuity of items treated and a neutral, scientific tone. The time was long gone when Buffon was honored both as scientist and writer. Wolf Lepenies comments that Buffon became famous for his style, rather than for his science. In the $19^{\text {th }}$ century, however, there occurs a move from Stilo primus, doctrina ultimus towards Doctrina primus, stilo ultimus (Lepenies 13). Science slowly drifted away from literature, though, Lepenies cautions, not in a linear or irreversible process. Some variation must be allowed also as concerns different national cultures (13). It can be shown, along the same line of investigation, that literature too, in its realistic and naturalistic currents, disputed with the social sciences the ability to study society, producing valid documents and knowledge (Lepenies 14-15).

Richard Burton, the most experienced and famous of all travel authors in the $19^{\text {th }}$ century, explicitly states his choice of accuracy over style in his Explorations of the Highlands of the Brazil:

While sketching the Highlands of Brazil as far as they were visited by me, my handywork is totally deficient in the "beautification" of which "serious travellers" complain. It is mostly a succession of hard, dry photographs with rough lines and dark, raw colours, where there is not a sing of glazing. The sketch, in fact, pretends only to the usefulness of accuracy. (10)

The reduced corpus under exam here supports Lepenies's view of the growing differentiation of fields. It can be safely stated that, while Eschwege felt at liberty to offer comments on the most different topics and include unverified data along with very pointed tables drawn from careful observation in the same volume, Tschudi assumed a more sober tone, keeping to one subject and presenting a detailed description of its various aspects. Eschwege was imbued with the notion of encyclopedic knowledge of the same kind, even if not at the same level of Goethe's, who was a paradigm of the intellectual in Germany and with whom the 
mineralogist had some personal contact. Goethe united literary greatness with a claim to scientific talent acknowledged by his contemporaries and a great many people still nowadays. Having made some minor but unchallenged discoveries in fields as wide apart as anatomy and mineralogy - and tried to devise a theory of colors - the greatest German poet stood as a proof of the possibility of universal knowledge. He can be seen, however, as the apex of an era. Specialization was soon after to win the day.

As a reader, Goethe can also furnish us a model of the reception of travel books in the first decades of the $19^{\text {th }}$ century. The record of his borrowings from the public library in Weimar shows a wide interest in travel books of any kind and a pointed focus on books about Brazil and Latin America. ${ }^{9}$ The notes in his diary, however, indicate that he read the books in search of specific information, mainly on exotic botanical species and on rocks and minerals. Curiously, he afterwards bought some of the books he had already read from the library, keeping their pages uncut. Also, he tried to get in contact with the authors, hoping to get specimens to examine personally. On his side, travel books were food for an eager curiosity and on the travelers' side, of course, drawing the attention of someone like Goethe was a great move towards success and reknown.

A new reader, however, was being born and spreading throughout Europe: the novel reader, responsible for the enormous expansion of the publishing business. The incipient cultural industry ${ }^{10}$ of the time consisted mostly of novels and operas, expanding to other entertainment books and stage performances. Among the entertainment books, travel narratives were an appealing genre. Already in the last decades of the $18^{\text {th }}$ century, "novels, travel books and Natural History works tended to take the place of the classics in the libraries" (Darnton, $O$ beijo de Lamourette 19).

Fully awake to the "rise of the novel," James Wells, an engineer who worked for a railway company in Brazil in the late 1870s, and who published in 1886 a two-volume book about his experiences in this 
country, tries to create interest by using procedures from fiction writing. His guide model is Dickens, whose Martin Chuzzlewithe cites several times in his text. He even compares himself repeatedly with Mark Tapley, one of the major characters in the novel. His emphasis on character sketching is unparalleled in non-fiction travel books about Brazil. Dialogues, a rare feature in the genre, make his Three Thousand Miles through Brazil lively and true to life:

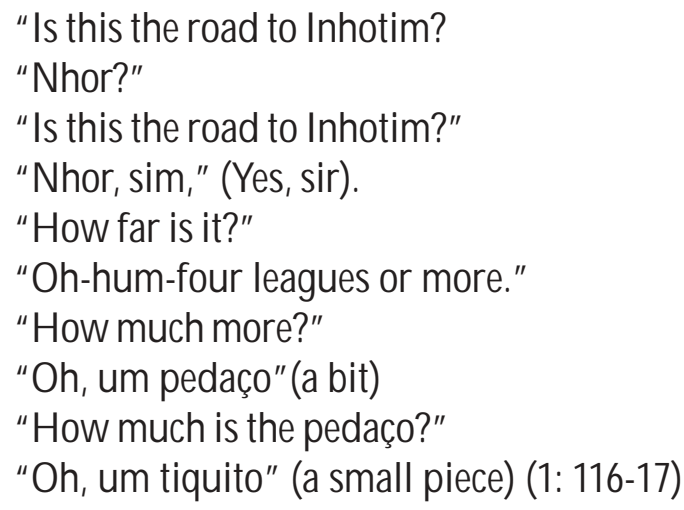

Genuine feelings pervade his pages; he lets his disappointment, resentment and homesickness show, alternating with humorous passages and exhilarating comments on landscape vastness and beauty. His book contrasts greatly with Tschudi's, considering their relative proximity in time, which also corroborates Wolf Lepenies description of the growing separation of scientific and literary cultures in the $19^{\text {th }}$ century.

James Wells intended to become a fiction writer, as his second book, a novel set in the Brazilian Amazon region, shows. The novel was a huge flop and, according to Christopher Hill, there is hardly a copy to be found in British libraries (30) ${ }^{11}$. In Wells's travel book, published two years earlier, he had tried his hand at literary writing and sought to establish himself as an author. The strategy was not bad in itself; an unknown traveler could have success in attracting a 
reasonable public who were primarily interested in information about the New World. Once captured, these readers would probably buy a second travel book, reporting on a similar journey. But, to put it in Pierre Bourdieu's terms ${ }^{12}$, Wells's sudden move to novel writing displays a lack of habitus and an ignorance of the state of the literary field that was fatal to him. With no nobility title or fortune to recommend the author, his name soon relapsed into oblivion.

Passing from the necessarily fragmented form of the travel book to the tight structure of the novel required more than mere will. Even if Wells resorted to fictional procedures, his first book was a mixture of journal notes, enumerations, collages of various kinds in the main text, followed by a glossary and eight appendices: A and B describe two different regions and their rivers, $\mathrm{C}$ presents tables of temperatures, and statistics of deaths and its causes in Rio; D deals with gold and diamond mines but includes statistics on railways; $E$ names and describes the various railway lines; F discusses foreign investment in sugar mills; G, more ambitious, concerns "the past, the present and the future of Brazil," reinforcing the arguments with tables of different kinds; $\mathrm{H}$ consists of extracts from a paper presented at a meeting of the Royal Geographic Society. By including this miscellaneous assemblage of data and commentary, Wells seems to imply that his audience was an interested one, in the sense that they might have, or would contemplate having, investments in Brazil. He explicitly intends to set the investors right about aspects of the country that could have some bearing on their shares' return.

Three Thousand Miles through Brazil is therefore a twofold book, offering entertainment as well as information, but never quite fulfilling either of its objectives. The idea that a cover with a general title and the name of an author will automatically transform a patchwork text into a whole - a book - still made up for the stylistic uncertainties of the traveler. However, the effort to "translate" his foreign experiences into the mental repertoire of his contemporaries, the struggle to keep down the level of new information and bringing whenever possible 
recognizable objects and habits of reasoning to the reader's mind is unprecedented. Wells's recourse to the "talk of the day" while telling of a distant country lost in time and space is remarkable: he repeatedly refers to fashionable operas and their arias, to novels and adventure books that were being read by his contemporaries, to the pleasures and taste of the Englishman of his time, as if he were trying to live simultaneously in both atmospheres, the exotic and the familiar, thus increasing the contrast between then and asserting the relative value of each. Christopher Hill, in his introduction to the Brazilian translation, does not seem impressed by this enterprise, but a postmodern reader may appreciate his endeavor as a fair consideration of each society in its own terms (which does not prevent his relapsing into the most caricatural eurocentrism occasionally. $)^{13}$

Keeping true to one's own experiences and living up to the expectation of a readers' audience were the two poles between which travelers balance themselves when making the collected material into a book. The question seems more complex if we consider that what is experienced is not reality in the raw, but the product of the mental operations of memory, always related to something previously known, that is to say, to previous texts. In order to be shared, experience must become a text. If writing has this unavoidable character of secondness, any text is a re-presentation in which verisimilitude takes the place of veracity. And, again, verisimilitude can only be measured against expectation created by previous reading.

Michel de Certeau compares the writing process to Robinson Crusoe's adventure: the island is the blank page, there is a conscience presiding over a system of objects (signs) and a resulting transformation of the "natural" world (227). The first impulse to write, in Crusoe, comes from the need to exert control over time and things, inscribing his will on the blank page of nature. Certeau reminds us that Rousseau wanted his Emile to read only Defoe's story and have no other book. And, indeed, Robinson Crusoe embodied for many generations the primal tale of man standing up by himself against the world: man creating his 
own Eden, after his own will - a new, enterprising Adam. This hero can be - and certainly was - seen as the model of all travelers. Crusoe, it must be remarked, was different from the early mythological figures of travelers, epitomized in Ulysses, in that he wrote a diary. He incorporates the notion that experience only acquires meaning as it originates a text. In this he is the modern man all over. No modern traveler since then would be contented to only travel, without writing ${ }^{14}$.

Defoe's novel was written in the beginning of the $18^{\text {th }}$ century (1719). A century later, the idea of printing a book had become a natural sequel to that of writing down one's experiences. Travelers' diaries were meant to be published, writing was no longer a value in itself. Although the author-reader one-to-one communication could still be idealized, the notion of an audience, of adapting the number of copies to the number of probable buyers, and of publishing as an objective business was well impressed in the writer's mind. The need to convince an editor to accept one's manuscripts followed naturally and - once acknowledged - directed the author's pen from the first rough draft on.

Nevertheless, there were, in $19^{\text {th }}$ century travel writing, protocols to be followed when presenting a first book. One of them was stating that the field diaries were not at first meant to be published: "although I kept a daily record of my progress and incidents, I did not do it with the intention to use it for publication" (Wells 34). Another was making excuses for the fragmented report, which was allegedly due to the hazardous conditions of the journey. And, of course, modesty had to be proclaimed by an unknown author, who had never before undertaken the task of writing a book: "I stop here, for I could not write authoritatively about this large and wonderful country, so attractive in many ways, after such a brief stay," concludes Ernest de Courcy (125). ${ }^{15}$ And, last but not least, in the face of so many drawbacks, some reason for having decided to publish after all must be pointed out. James Wells's ground of defense was his good knowledge of the language and the amount of his "concrete experiences" after a twenty-year residence in Brazil. Richard Burton, 
eighteen years before, felt no need for excuses, since his name was already enough known to sanction his writing.

Dedications are another telling feature. They go back to the time when every book had to have the royal imprimatur. Eschwege, in the Portugal of the early 1800, would still be under the obligation of obtaining a royal license. The fact that he published in Germany did not dispense him, however, from trying to get the attention of the Kurfürst he was subjected to. In fact, he uses the pledge of loyalty to justify his book: "I owe Your Royal Highness the account of how I spent my time abroad" (1:52). Richard Burton displays more independence when he dedicates his book to Lord Stanley. Recognizing him as his superior in rank, Burton at the same time addresses him as a "colleague anthropologist." Two decades later, James Wells speaks directly to the common reader, as a novel writer would. Ernest de Courcy, a French Vîcomte, publishing in 1886, dedicates his work to his daughter, as if trying, by choosing a closer and humbler addressee, to protect his text from criticism.

This discussion of the questions involving the publication of travel books - here, exclusively those about Brazil - could only lead to more material results if the complete corpus were systematically analyzed. The present text intends only to call attention to an aspect of the genre that has been often disregarded, but will, tentatively, present some first conclusions. Summing up the above exposition, some general statements can safely be made: 1. travel entails writing, writing entails printing. The act of writing a book distinguishes the traveler from the tourist and/or businessman. 2. travel endorses writing: the experience of travel justifies one's turning into an author. 3. veracity and originality are the two pillars supporting travel writing and minimizing its flaws. (Non superior sed veritas is the motto closing de Courcy's book) 4 . Audience expectations have a growing influence in a book's structure as the $19^{\text {th }}$ century advances. 5 . Travel books published along the $19^{\text {th }}$ century show the progressive division between the scientific and the literary fields. 
If the above commentaries have not been enough to distinguish the notion of "book" from that of "writing" - since it is a very fixed habit of ours to think of a book as a correlate of its content-the following story may make the difference clear: Robert Burton finished his book on Brazilian travels in 1868 and gave the manuscripts to his wife to have them published in England. On her arrival, and following the dictates of her consciousness, she added a preface in which she condemned some of the ideas professed by her husband in the text. This gesture is demonstrative of the process of making a manuscript into a book: the volume issued suffers (mostly unacknowledged) interferences from the editor and the publishing house, in the form of the paper, type and ink used, the title and the cover, even to the insertion of notes, introduction, preface and jacket. Above all, a book is a lonely voyager for whom his creator can no longer respond.

Each and every one of the foreign travelers in Brazil, while addressing a non-Brazilian audience, contributes his share to transform that country into a valid and consistent textual subject. Their various achievements and their critical fortune in their own countries are a part of what is nowadays being recovered as a History of the Book and a History of Reading. For Brazilians, however, they remain the ones who, by describing the country, taught so many of its fictional writers to look at it as a singular object. ${ }^{16}$

\section{Notes}

1. However, Isabel Burton complains, in an introductory note to Explorations of the Highlands of Brazil, that, while her husband counts on faithful readers, she, as assistant in the finishing and publishing of his book, remains in his shadow, unknown to the public.

2. Some reference will be made of other travel authors, namely Richard Burton and the Viscount of Courcy.

3. Igot the assignment from Fundação João Pinheiro, Government of Minas Gerais, in the late nineties. The translations are part of the Coleção Mineriana, which includes 
other travelers' books and studies on the culture history of Minas Gerais. The person responsible for the series at the time was Roberto Borges Martins.

4. However, Eschwege's Pluto Brasiliensis was read and quoted by Karl Marx in Das Kapital.

5. H.J.F. Halfeld and Friedrich Wagner.

6. In his introductory study to Brasil, novo mundo.

7. This effect is even today observable in the tendency of the common reader to see a first person narrator as an impersonation of the author.

8. Ver Darnton, O beijo de Lamourette: mídia, cultura e revolução.

9. This information was gathered by me on location, during a research sponsored by the Weimar Classicism Foundation (Stiftung Weimarer Klassiker) in 2000. An essay on the subject of Goethe's interest in Brazil can be found in my book Oretrato na rua.

10. For a specification of the term, and a discussion of the beginnings of culture industry, see Rodrigo Duarte, Teoria crítica da indústria cultural.

11. Hill found a copy of The Voice of Urbano: a Romance of Adventures on the Amazons (1888) in the Bodleian Library in Oxford with its pages uncut after more than century. See his introduction to Três mil milhas através do Brasil.

12. Bourdieu elaborates extensively on the concepts of habitus and literary field in various of his books. See, for instance, Rules of Art: Genesis and Structure of the Literary Field, Stanford University Press, 1996.

13. More on Wells in my articles "Guimarães Rosa and the look of the foreigner in travel literature" (D'haen, T. and Krüs, P. Colonizer and colonized. Amsterdam Atlanta,GA, Rodopi, 2000) and "The literary construction of the sertão in James Wells's Three thousand miles throuhg Brazil"' (Brasil/Brazil, n.34, year 19/20052006).

14. In the 20th century, Walter Benjamin presents the traveler as the exemplary narrator. Some elaboration on the question can be found in my essay "Peripatografias," in Ávila (O retrato na rua 80-93). 
15. The Brazilian translator stresses in an introductory note the excessive number of print errors in the French edition, which could be a sign of the little importance given to the edition by the publisher.

16. See, for the association of travel narrative and the fiction narrator in Brazilian literature, Flora Süssekind's book O Brasil não é longe daqui.

\section{References}

Ávila, Myriam. O retrato na rua. Belo Horizonte: Ed.UFMG, 2008.

Bourdieu, Pierre. As regras da arte. Trans. Maria Lúcia Machado. São Paulo: Companhia das Letras, 1996.

. Rules of Art: Genesis and Structure of the Literary Field. Stanfor: Stanford UP, 1996.

Burton, Richard. Explorations of the highlands of the Brazil. London: Tinsley Brothers, 1869.

Certeau, Michel de. A invenção do cotidiano. Artes do fazer. Trans. Ephraim Ferreira Alves. Petrópolis: Vozes, 1994.

Courcy, Visconde Ernest de. Seis semanas nas minas de ouro do Brasil. Trans. Júlio Castañon Guimarães. Belo Horizonte: Fundação João Pinheiro, 1997.

Darnton, Robert. O beijo de Lamourette: mídia, cultura e revolução. Trans. Denise Bottmann. São Paulo: Companhia das Letras, 1990.

. "História da leitura". A escrita da história: novas perspectivas. Ed. Peter Burke. Trans. Magda Lopes. São Paulo: Unesp, 1992. 199-236.

Duarte, Rodrigo. Teoria crítica da indústria cultural. Belo Horizonte: Ed. UFMG, 2003.

Eschwege, W. L. von. Brasil, novo mundo. Vol.1. Trans. Domício de Figueiredo Murta. Belo Horizonte: Fundação João Pinheiro, 1996.

Brasil, novo mundo. Vol.2. Trans. Myriam Ávila. Belo Horizonte: Fundação João Pinheiro, 2000. 
Hill, Christopher. Introdução. In: Wells, James W. Três mil milhas através do Brasil. Trad. Myriam Ávila. Belo Horizonte: Fundação João Pinheiro, 1995. 1-32.

Lepenies. Wolf. As três culturas. Trans. Maria Clara Cescato. São Paulo: Edusp, 1996.

Renger, Friedrich E. Estudo introdutório. In: Eschwege, W. L. von. Brasil, novo mundo. Vol.2. Trans. Myriam Ávila. Belo Horizonte: Fundação João Pinheiro, 2000. 11-20.

Süssekind, Flora. O Brasil não é longe daqui: o narrador; a viagem. São Paulo: Companhia das Letras, 1990.

Tschudi, JJ. Von, e H. G. Halfeld. A província brasileira de Minas Gerais. Trans. Myriam Ávila. Belo Horizonte: Fundação João Pinheiro, 1998.

Wells, James W. Três mil milhas através do Brasil. Trans. Myriam Ávila. Belo Horizonte: Fundação João Pinheiro, 1995.

. Exploring and Travelling Three Thousand Miles through Brazil from Rio do Janeiro to Maranhão. London: Sampson, Low, Marston, Searle, \& Revington, 1886. 
